\title{
Fiscal policy sustainability: some unpleasant European evidence*
}

\author{
António Afonso \\ Department of Economics, \\ Instituto Superior de Economia e Gestão, \\ Universidade Técnica de Lisboa, \\ R. Miguel Lúpi, 20, \\ 1249-078 Lisbon, \\ Portugal \\ Tel.: +351213922807 \\ Fax: +351213966407 \\ e-mail: aafonso@iseg.utl.pt
}

This version: August 2000

\begin{abstract}
The sustainability of fiscal deficits has been receiving increasing attention from economists. The issue is paramount for the newly formed Euro area and this is one of the motivations of the paper. In order to assess the sustainability of budget deficits in the Euro area, stationarity tests for the stock of public debt and co-integration tests between public expenditures and public revenues are performed for the Euro countries for the 1968-1997 period. The empirical results allow us to conclude that fiscal policy may not be sustainable for most countries with the possible exceptions of Germany, Austria and the Netherlands.
\end{abstract}

Keywords: Deficit finance; inter-temporal budget constraint; fiscal policy sustainability; Euro area

JEL classification: E60; H62; H63

\footnotetext{
" This paper is part of the research project for the author's Ph.D. thesis. The author acknowledges comments from Jorge Santos, participants in the 2000 Annual Meeting of the European Public Choice Society Conference in Siena, April 2000, participants in the $5^{\text {th }}$ Conference of Theories and Methods in Macroeconomics (T2M) in Nanterre, May 2000, and participants at the Economics Department Seminar of ISEG in Lisbon, May 2000. The usual disclaimer applies.
} 
"...the government's intertemporal budget constraint is a constraint on the government's instruments that must be satisfied for all admissible values of the economy-wide endogenous variables," Buiter (1999).

\section{1 - Introduction}

In recent years several developed countries have been facing significant fiscal deficits. The government's ability to cope with fiscal deficits has been receiving increasing attention from economists. Fiscal sustainability seems quite a recurrent topic that both individual countries and international organisations dwell upon with some regularity. ${ }^{1}$ The issue is paramount for the newly formed Euro area and this is one of the motivations of this paper.

Already quite a lot of literature has studied the issue of fiscal policy sustainability and empirically tested the present value borrowing constraint. Examples of such a growing literature are for instance Hamilton and Flavin (1986), Trehan and Walsh (1988, 1991), Kremers (1988, 1989), Wilcox (1989), Hakkio and Rush (1991), Tanner and Liu (1994), Quintos (1995), Haug (1991, 1995), Ahmed and Rogers (1995), Uctum and Wickens (1997), Crowder (1997), Payne (1997) and Artis and Marcelino (1998). The main tools used to analyse the sustainability of budget deficits seem to be stationarity tests for the stock of public debt and co-integration tests between government expenditures and government revenues.

The paper is organised as follows: the next section offers some considerations on the arithmetic of budget deficits; section three reviews the theoretical framework of budget deficits sustainability and the approaches used in the literature to validate the sustainability of fiscal policy. Stationarity tests and co-integration test results, between government expenditures and government revenues for the EU-15 countries, are the main focus of section four. Section five is a conclusion.

\footnotetext{
${ }^{1}$ See for instance Chalk and Hemming (2000).
} 


\section{2 - The arithmetic of budget deficits and public debt}

Previous to the sustainability issue, a review of the fiscal deficit arithmetic seems to be in order, to help set the theoretic framework for the subsequent sustainability analysis.

The government borrowing constraint for period $t$ may be written with the following dynamic equation

$$
B_{t}=\left(1+i_{t}\right) B_{t-1}+G_{t}-R_{t}-\left(M_{t}-M_{t-1}\right)
$$

were the variables are defined as follows: $G$ - government expenditures, excluding interest payments; $R$ - government revenues; $B$ - public debt; $i$-nominal interest rate, implicit in public debt; $M$ - nominal monetary base. It is possible to simplify the notation namely by suppressing the time indexes,

$$
\Delta B=G-R+i B-\Delta M
$$

In order to analyse the evolution of the debt-to-GDP ratio it is necessary to compute the total derivative of $\mathrm{B} / \mathrm{Y}$ :

$$
d\left(\frac{B}{Y}\right)=\frac{1}{Y} d B+\left(-\frac{B}{Y^{2}}\right) d Y
$$

or, with a notation similar to the one in equation (2),

$$
\Delta\left(\frac{B}{Y}\right)=\frac{\Delta B}{Y}-\frac{B}{Y} \frac{\Delta Y}{Y} .
$$

Defining $b=B / Y$ and $n=\Delta Y / Y$, the preceding equation is also identical to

$$
\Delta b=\frac{\Delta B}{Y}-b n .
$$


Substituting (2) in (5) gives,

$$
\Delta b=\frac{G+i B-R}{Y}-\frac{\Delta M}{Y}-b n
$$

and after defining $g=G / Y$ and $\rho=R / Y$,

$$
\Delta b=g+i b-\rho-\frac{\Delta M}{Y}-b n
$$

Assuming $\lambda$ as the growth rate of monetary base, $\lambda=\Delta \mathrm{M} / \mathrm{M}$, and defining also $m=M / Y$,

$$
\frac{\Delta M}{M} \frac{M}{Y}=\lambda m
$$

and using equations (9) and (8),

$$
\Delta b=g+i b-\rho-\lambda m-b n,
$$

it is then possible to write the long-run budget constraint, which means that $\Delta b=0$, as

$$
n b=g+i b-\rho-\lambda m
$$

in words, the long-run deficit will be proportional to the level of public debt and the economy nominal growth rate is the proportionality factor.

The previous equation is useful to perform some simple and illustrating calculations. Assume that the debt-to-GDP ratio is stable at 60 per cent and that the economy nominal growth rate is 4,5 per cent in annual terms. Then the government will end up to incur in an annual deficit of 2,7 per cent of GDP (deficit $=4,5 \times 0,6=2,7$ per cent). 
Using the Fisher relation for the interest rate, $r=i-\pi$ and for the economy growth rate, $n=y+\pi$, we have

$$
\Delta b=g-\rho-\lambda m+b(r-y),
$$

a formulation identical to the one present throughout the literature (see for instance Buiter (1985) and Spaventa (1987)).

With equation (11) it is possible to confirm the explosive characteristic of the debt-to-GDP ratio when $r>y$. In fact, the debt-to-GDP ratio increases when the real interest rate is above the real GDP growth rate and when the government has primary deficits. Finally, assuming again that the debt-to-GDP stabilises at a certain level, it is possible to solve equation (11) for $b$, which gives,

$$
b=(\rho-g+\lambda m) /(r-y) .
$$

The budget constraint in equation (9) is really a differential equation in a continuous time scenario, that is (forgetting for simplicity money financing),

$$
\dot{b_{t}}=d_{t}-n b_{t}
$$

where $d_{t}$ is the budget deficit as a percentage of GDP in period t. With the hypothesis of balanced budgets, $d_{t}=0$, we have

$$
\dot{b_{t}}=-n b_{t}
$$

The solution of the above differential equation may be written as

$$
b_{t}=C e^{-n t}
$$

and, in the long-run, this expression approximates zero since $\lim _{t \rightarrow \infty}\left[C e^{-n t}\right]=0$. 
Figure 1 illustrates the evolution of the debt-to-GDP ratio when there is a balanced budget and the annual nominal growth rate of GDP is 5 per cent, and it is possible to see that assuming a positive growth rate one gets a declining debt-to-GDP ratio.

\section{[Insert Figure 1 about here]}

Some calculations where also made in order to understand the possibility of several combinations of government expenditures and government revenues together with different debt-to-GDP ratios. A real GDP growth rate of 2,5 per cent was used, also with an inflation rate of 2 per cent along with a level of 40 per cent of GDP for government revenues and expenses.

Three alternative hypotheses for the real interest rate were also used. The calculations were made as follows: first, the deficit is computed for the several values of the debt-to-GDP ratio, then the interest expenses are calculated and finally the government revenues (expenditures) are derived holding the government expenditures (revenues) constant. Table 1 presents the results of the simulations.

\section{[Insert Table 1 about here]}

Suppose for instance that government expenditures are 40 per cent of GDP and that government revenues must adjust in order for the long run budget constraint to be satisfied. Since we have $r>y$, the bigger the debt-to-GDP ratio the bigger the necessary increase of public receipts.

Also, the bigger the difference between the real interest rate and the real growth rate, the higher should be the level of government revenues as a percentage of GDP. Another conclusion is that as the debt-to-GDP ratio increases, the growth rate of government revenues is smaller than the growth rate of the public debt interests. As a matter of fact, it is important to notice that the effective cost of financing an additional deficit unit is just $r-y$. That is because a part of the total cost of that additional deficit 
unit is financed through new debt, the stock being increased at the same rate of the real GDP growth rate.

Identical calculations may be carried out in order to show that higher levels of deficits and public debt may be consistent with a reduction of government expenditures, as an alternative to the increase of government revenues. In this case, a higher public indebtedness is associated with a decrease of government expenditures, at a lower rate than the increase of the public debt interests. Observe nevertheless that all these calculations are simple static exercises, not taking into account for instance that the level of the stock of public debt may have some influences on real GDP growth rate, on the real interest rate and on inflation. ${ }^{2}$

The consequences of choosing different fiscal policies may also be exemplified by looking at the public debt paths of the US and Italy. In 1970 the debt-to-GDP ratio was 38 per cent in both countries as can be seen in Figure 2. However, during the period 1970-1990 Italy had an average public deficit of 9 per cent of GDP while the US had an average deficit of only 2,2 per cent of GDP. The result was that in 1999 public debt was 116 per cent and 64 per cent of GDP respectively in Italy and in the US. Even if we take into account the different GDP growth rates in the two countries, adding up successive and significant budget deficits in Italy had a clearly identifiable impact on government debt.

[Insert Figure 2 about here]

\section{3 - The sustainability issue}

The sustainability of fiscal policy is sometimes confused with the financial solvability of the government. In practice however, what the empirical literature ends up testing is whether both public expenditures and government revenues may continue to display in the future their historical growth patterns. This seems really to be the issue here, not so much a question of solvability.

\footnotetext{
${ }^{2}$ A macroeconomic model would be necessary for that purpose. See for instance the paper of Macklem, Rose and Tetlow (1995) for Canada.
} 
If a given fiscal policy turns out to be unsustainable, it has to change in order to guarantee that the future primary balances are consistent with the budget constraint. ${ }^{3}$ Theoretically any value for the budget deficit would be possible if the government could rise its liabilities without limit. Obviously, that is impossible since the government is faced with the present value of its own budget constraint.

In the beginning of the $20 \mathrm{~s}$, when writing about the public debt problem faced by France, Keynes (1923) alerted to the need for the French government to conduct a sustainable fiscal policy in order to satisfy its budget constraint. Keynes stated that the absence of sustainability would be evident when

"the State's contractual liabilities (...) have reached an excessive proportion of the national income" (p. 54).

In modern terms, sustainability is challenged when the debt-to-GDP ratio reaches an excessive value. There is a problem of sustainability when the government revenues are not enough to keep on financing the costs associated to new issuance of public debt or, in Keynes's words, when

"it has become clear that the claims of the bond-holders are more than the tax payers can support" (p. 55).

At that stage the government will have to take measures that allow regaining the sustainability of fiscal policy, that is the State

"must come in due course to some compromise between increasing taxation, and diminishing expenditure, and reducing what (...) [it] owe[s]" (p. 59).

Blanchard et al (1990) present as a definition of sustainable fiscal policy one that allows, in the short term, that the debt-to-GDP ratio returns to its original level after some excessive variation. Put another way, for a fiscal policy to be sustainable, after

\footnotetext{
${ }^{3}$ Cuddington (1997) and Hénin (1997) discuss this topic.
} 
having accumulated debt in the past, the government must run primary surpluses in the future.

It is worthwhile noticing that the hypothesis of fiscal policy sustainability is related to the condition that the trajectory of the main macroeconomic variables is not affected by the choice between the issuance of public debt or the increase in taxation. Under such conditions, it would therefore be irrelevant how the deficits are financed, implying also the validation of the Ricardian Equivalence issue. ${ }^{4}$

In short, two alternative definitions for fiscal policy or budget deficit sustainability may be presented, to be analytically derived on the next section:

i) the value of public current debt must be equal to the sum of future primary surpluses;

ii) the present value of public debt must approach zero in infinity.

\section{1 - The present value of the budget constraint}

The government budget constraint is naturally the starting point to derive the present value of the budget constraint. Writing once more the budget constraint, now in real terms, a more adequate presentation for posterior analytical developments, ${ }^{5}$ we have

$$
G_{t}+\left(1+r_{t}\right) B_{t-1}=R_{t}+B_{t}
$$

with $G$ - government expenditures, in real terms, excluding interest payments; $R$ government revenues, in real terms; $B$ - public debt in real terms; $r$ - real interest rate.

\footnotetext{
${ }^{4}$ Caporale (1995) mentions this question. Afonso (1999) presents some empirical results on the feasibility of Ricardian Equivalence in the Euro area.

${ }^{5}$ Note that sometimes in the literature, for the validation of theoretical results, the real interest rate is assumed stationary, but this is a much more difficult assumption for the nominal interest rate. For instance Crowder (1997) reports empirical evidence that supports the fact that nominal interest rate is nonstationary for the USA.
} 
Rewriting equation (16) for periods $t+1, t+2, t+3, \ldots$, and recursively solving that equation leads to the following intertemporal budget constraint

$$
B_{t}=\sum_{s=1}^{\infty} \frac{R_{t+s}-G_{t+s}}{\prod_{j=1}^{s}\left(1+r_{t+j}\right)}+\lim _{s \rightarrow \infty} \prod_{j=1}^{s} \frac{B_{t+s}}{\left(1+r_{t+j}\right)}
$$

When the second term from the right-hand side of equation (17) is zero, then the present value of the existing stock of public debt will be identical to the present value of future primary surpluses. Also, when the limit term is zero, this means that in the long run the government will have to stop using Ponzi games to finance fiscal deficits.

Equation (17) is not appropriate for empirical testing. It is therefore adequate to make several algebraic modifications to equation (16). Assuming that real interest rate is stationary, with mean $r$, and defining

$$
E_{t}=G_{t}+\left(r_{t}-r\right) B_{t-1},
$$

it is possible to obtain the following expression

$$
B_{t-1}=\sum_{s=0}^{\infty} \frac{1}{(1+r)^{s+1}}\left(R_{t+s}-E_{t+s}\right)+\lim _{s \rightarrow \infty} \frac{B_{t+s}}{(1+r)^{s+1}}
$$

A sustainable fiscal policy should assure that the present value of the stock of public debt goes to zero in infinity, which means taking into account the following transversality condition, constraining the debt to grow no faster than the interest rate,

$$
\lim _{s \rightarrow \infty} \frac{B_{t+s}}{(1+r)^{s+1}}=0
$$

or, in other words, it means to impose the absence of Ponzi games and the fulfilment of the intertemporal budget constraint. ${ }^{6}$ By imposing the transversality condition, the

\footnotetext{
${ }^{6}$ Also quoted in the literature as the "no-Ponzi game condition."
} 
government will have to present in the future primary surpluses whose present value add up to the current value of the stock of public debt. Still another way of putting it is that public debt in real terms cannot increase indefinitely at a growth rate beyond real interest rate. ${ }^{7}$

Let us now proceed with the derivation of the solvency condition, with all the variables defined as a percentage of GDP. For instance Hakkio and Rush (1991, pp. 430) support that an analysis based on ratios is more appropriated for growing economies:

"(...) in addition to examining revenue and spending directly, we also use normalize these variables using real GNP and population. This is an important extension beyond previous work since McCallum [1984], among others, deems these ratios - per capita spending and revenue, and spending and revenue as a fraction of GNP - as more pertinent for a growing economy."

The present value of the borrowing constraint, with the variables expressed as a percentage of GDP, and neglecting for presentation purposes seigniorage revenues, is written as

$$
\frac{B_{t}}{Y_{t}}=\frac{\left(1+r_{t}\right)}{\left(1+y_{t}\right)} \frac{B_{t-1}}{Y_{t-1}}+\frac{G_{t}}{Y_{t}}-\frac{R_{t}}{Y_{t}}
$$

By means of a similar procedure to the one we obtained equation (19), where real interest rate is assumed stationary, with mean $r$, and considering also a constant real economic growth rate, the budget constraint is then given by

$$
b_{t-1}=\sum_{s=0}^{\infty}\left(\frac{1+y}{1+r}\right)^{(s+1)}\left[\rho_{t+s}-e_{t+s}\right]+\lim _{s \rightarrow \infty} b_{t+s}\left(\frac{1+y}{1+r}\right)^{(s+1)}
$$

with $b_{t}=B_{t} / Y_{t}, e_{t}=E_{t} / Y_{t}$ and $\rho_{t}=R_{t} / Y_{t}$.

\footnotetext{
${ }^{7}$ See Joines (1991). McCallum (1984) discusses if this is a necessary condition to obtain an optimal growth trajectory for the stock of public debt.
} 
When $r>y$, a characteristic of a dynamically efficient economy, ${ }^{8}$ it is necessary to introduce a solvency condition in order to bound public debt growth. This implies that the growth rate of the debt-to-GDP ratio should be less than the factor $\left(\frac{1+y}{1+r}\right)^{(s+1)}$, being the transversality condition given by

$$
\lim _{s \rightarrow \infty} b_{t+s}\left(\frac{1+y}{1+r}\right)^{(s+1)}=0
$$

Using the budget constraint, equation (22), and the solvency condition, equation (23), we get

$$
b_{t-1}=\sum_{s=0}^{\infty}\left(\frac{1+y}{1+r}\right)^{(s+1)}\left[\rho_{t+s}-e_{t+s}\right]
$$

the by now familiar result that fiscal policy will be sustainable if the present value of the future stream of primary surpluses, as a percentage of GDP, matches the "inherited" stock of public debt. ${ }^{9}$

\section{2 - Assessment of the sustainability of public deficits}

Returning to equation (19), it is now possible to present analytically two complementary definitions of sustainability, which set the background for most empirical testing:

i) the value of public current debt must be equal to the sum of future primary surpluses

$$
B_{t-1}=\sum_{s=0}^{\infty} \frac{1}{(1+r)^{s+1}}\left(R_{t+s}-E_{t+s}\right),
$$

\footnotetext{
${ }^{8}$ See for instance Abel et al (1989) and Frisch (1995).

${ }^{9}$ According to Buiter (1999), the intertemporal government budget constraint should be satisfied always and not only in equilibrium. This is Buiter's main criticism to the fiscal theory of price level, a topic beyond the scope of this paper.
} 
ii) the present value of public debt must approach zero in infinity

$$
\lim _{s \rightarrow \infty} \frac{B_{t+s}}{(1+r)^{s+1}}=0 .
$$

The literature exhibits generically two main approaches to test the sustainability hypothesis: tests similar to the one suggested by Trehan e Walsh (1991) and tests like the one credited to Hakkio e Rush (1991).

\section{Trehan and Walsh (1991)}

In order to test empirically the absence of Ponzi games, the authors propose to test the stationarity of the first difference of the stock of public debt. It is therefore necessary for $(1-\mathrm{L}) \mathrm{B}_{\mathrm{t}}$ to be a stationary process, where $\mathrm{L}$ is the lag operator. ${ }^{10}$ To test for the stationarity of the (1-L) $B_{t}$ series, it is possible to use the unit root tests developed by Dickey and Fuller $(1979,1981)$. Trehan and Walsh (1991) assume also that the real interest rate is not constant, and that a stochastic process may represent it. ${ }^{11}$ The stationarity tests for $(1-\mathrm{L}) \mathrm{B}_{\mathrm{t}}$ are conducted using

$$
(1-L)^{2} B_{t}=\lambda+\alpha t+\beta_{0}(1-L) B_{t-1}+\sum_{i=1}^{m} \beta_{i}(1-L)^{2} B_{t-i}+u_{t}
$$

with the null hypothesis given by $H_{0}: \beta_{0}=0, H_{1}: \beta_{0}<0$.

If the null hypothesis is rejected, then the process $(1-\mathrm{L}) \mathrm{B}_{\mathrm{t}}$ is stationary and the sustainability hypothesis may be accepted. If on the other hand the null is not rejected, then the process $(1-\mathrm{L}) \mathrm{B}_{\mathrm{t}}$ may only be stationary in the first differences, which can mean sustainability problems. As observed by Trehan and Walsh (1991), the stationarity of the variation of the stock of public debt is a sufficient condition, and stationarity

\footnotetext{
${ }^{10}$ For instance Sawada (1994) also uses this approach to study the sustainability of external debt in several Southeast Asia and South America countries.

${ }^{11}$ Hénin (1997), supports that in a deterministic context sustainability appears as a stability condition, while as in a stochastic context sustainability is perceived as the existence or not of a stationary process for public debt.
} 
rejection does not necessarily imply the absence of sustainability of the government accounts. $^{12}$

\section{Hakkio and Rush (1991)}

Hakkio and Rush (1991) initially developed the empirical approach of the sustainability of fiscal policy through co-integration tests. The implicit hypothesis concerning the real interest rate, with mean $r$, is also stationarity. The intertemporal budget constraint, equation (17), may also be written as ${ }^{13}$

$$
G_{t}+r_{t} B_{t-1}-R_{t}=\sum_{s=0}^{\infty} \frac{1}{(1+r)^{s-1}}\left[\Delta R_{t+s}-\Delta G_{t+s}-\Delta r_{t+s} \Delta B_{t-1+s}+r \Delta B_{t-1+s}\right]+\underset{\rightarrow \infty}{\lim \frac{B_{t+s}}{(1+r)^{s+1}},}
$$

and using once more the auxiliary variable $E_{t}=G_{t}+\left(r_{t}-r\right) B_{t-1}$, we arrive to

$$
G_{t}+r_{t} B_{t-1}-R_{t}=\sum_{s=0}^{\infty} \frac{1}{(1+r)^{s-1}}\left(\Delta R_{t+s}-\Delta E_{t+s}\right)+\lim _{s \rightarrow \infty} \frac{B_{t+s}}{(1+r)^{s+1}} .
$$

With the no-Ponzi game condition, $\lim _{s \rightarrow \infty} \frac{B_{t+s}}{(1+r)^{s+1}}=0$, and with the additional definition

$$
G G_{t}=G_{t}+r_{t} B_{t-1}
$$

it is possible to derive

$$
G G_{t}-R_{t}=\sum_{s=0}^{\infty} \frac{1}{(1+r)^{s-1}}\left(\Delta R_{t+s}-\Delta E_{t+s}\right)+\lim _{s \rightarrow \infty} \frac{B_{t+s}}{(1+r)^{s+1}}
$$

\footnotetext{
${ }^{12}$ See Trehan and Walsh (1991).

${ }^{13}$ See Hakkio and Rush (1991).
} 
where $G G_{t}$ and $R_{t}$ must be co-integrated variables of order one for their first differences to be stationary.

Assuming that $R$ and $E$ are non-stationary variables, and that the first differences are stationary variables, implying that the series $R$ and $E$ in level are $\mathrm{I}(1)$, then for equation (31) to hold, the left-hand side of equation (31), will also have to be stationary. If it is possible to conclude that $G G$ and $R$ are integrated of order 1, these two variables should be co-integrated with co-integration vector $(1,-1)$, for the left-hand side of equation (31) to be stationary.

The usual procedure to assess the sustainability of the intertemporal government budget constraint involves testing the following co-integration regression ${ }^{14}$

$$
R_{t}=a+b G G_{t}+u_{t}
$$

The null hypothesis of no co-integration, that is, the hypothesis that the two I(1) variables are not cointegrated, is rejected if a high-test statistic is obtained implying that one should accept the alternative hypothesis of co-integration. For that result to hold true, the series of the residuals $u_{t}$ must be stationary, and should not display a unit root. $^{15}$

The empirical results may allow establishing several conclusions concerning the sustainability of the intertemporal budget constraint:

i) when there is no co-integration the fiscal deficit is not sustainable;

ii) when there is co-integration with $b=1$, the deficit is sustainable,

\footnotetext{
${ }^{14}$ In short, two variables are said to be co-integrated when each variable by itself is not stationary, but there is a linear combination of the two variables which is stationary, and it may exist a value of $a$ and $b$ such that $R_{t}-b G G_{t}-a=u_{t}$ is stationary. If the two variables are cointegrated, they cannot deviate from the co-integration relation beyond constant fluctuations bands, since $u_{t}$ has a constant variance.

${ }^{15}$ Fève and Hénin (1998) propose an alternative test for unit roots, the test FADF (Feedback Augmented Dickey Fuller) which, according to the results presented by the authors, is better than the ADF tests. Using the FADF test, the null hypothesis of non-stationarity is less often accepted than with the ADF test. For the sustainability issue, the sustainability hypothesis would be less often rejected than with the ADF test.
} 
iii) when there is co-integration, with $\mathrm{b}<1$, government expenditures are growing faster than government revenues, and the deficit may not be sustainable. $^{16}$

Hakkio and Rush (1991) demonstrate also that if $G G$ and $R$ are non stationary variables in level, the condition $0<\mathrm{b}<1$ is a sufficient condition for the budget constraint to be obeyed. However, when revenues and expenses are expressed as a percentage of GDP or in per capita terms, it is necessary to have $b=1$ in order for the trajectory of the debt-to-GDP not to diverge in an infinite horizon. ${ }^{17}$

Before proceeding it seems adequate to close the present section summarising the empirical findings of several other papers, concerning the sustainability issue. Table 2 sums up the conclusions of some of those papers.

[Insert Table 2 about here]

\section{4 - Fiscal policy sustainability in the EU-1 5 area}

\section{1 - Some historical facts}

A brief characterisation of the debt and fiscal burden on GDP, for the EU countries, seems appropriate before performing the empirical testing of the sustainability hypothesis.

Between the end of the 60s and the end of the 90s there was an increasing trend of the debt-to-GDP ratio for most countries throughout the period. For instance, public debt rose in Italy from 38 per cent of GDP in 1970 to 118 per cent of GDP in 1998. In Germany the debt-to-GDP ratio was 18,6 per cent in 1970 and went beyond the 60 per cent level in the 1996. Also in Portugal, public debt progressed from 15,4 per cent of GDP in 1974 to 60 per cent in 1998.

\footnotetext{
${ }^{16}$ Concerning this cointegration analysis approach Bohn $(1991,1995)$ argues that a sustainable fiscal policy in a certain environment, may bacome unsustainable under uncertainty.

${ }^{17}$ Quintos (1995), Ahmed and Rogers (1995) and Bergman (1998) discuss the necessary conditions for the sustainability in terms of the order of integration of public debt.
} 
The highest reported debt-to-GDP ratios are in Italy and Belgium (the country with the highest ratio in the period from 1970 to 1998: 135,2 per cent in 1993), around 118 per cent of GDP in 1998, and their high debt service payments induce substantial budget deficits despite primary budget surpluses. A reversal of that general trend is observable only in the end of the $90 \mathrm{~s}$, as the countries naturally tried to fulfil the Maastricht criterion on the debt-to-GDP ratio.

Concerning public expenditures and public revenues, Table 3 presents those items as a percentage of GDP for each country. The main conclusion is that the burden of public expenditures and revenues on GDP has increased since the 70s for almost every country. Also another obvious fact is that for most countries, the ratio of government expenditures to GDP exhibited a higher growth rate than the ratio of government revenues to GDP. This conclusion holds for all countries except for Ireland, Italy and Sweden.

\section{[Insert Table 3 about here]}

For instance in Portugal, the ratio of government revenues and expenditures to GDP was respectively 15,9 and 17,6 per cent in 1970, while those ratios where at 39,9 and 42,2 per cent in 1996. The case of Ireland is quite remarkable since the ratio of public expenditures to GDP actually decreased around 3,5 percentage points between 1970 and 1997, and one must bear in mind the high real GDP growth rates of Ireland during the 90 s.

\section{2 - Public debt stationarity tests}

The focus of this section is the study of public debt stationarity for each of the EU-15 countries. Augmented Dickey-Fuller tests are used in the attempt to validate the sufficient sustainability condition, and the variable used is the stock of public debt. Table 4 gives the stationarity tests results for the first difference of the stock of public debt, with the data used in real terms, at 1990 prices, for the period 1970-1998. 
[Insert Table 4 about here]

The results show that the process $(1-\mathrm{L}) \mathrm{B}_{\mathrm{t}}$ is stationary (at a 5 per cent level), the series of the first difference of public debt are I(0), for Austria, Germany and Netherlands. In other words, the solvency condition would be satisfied for only those three countries. For the remaining countries, the rejection of the stationarity hypothesis does not mean, as already noticed above, the insolvency of public accounts since the above hypothesis is only a sufficient condition and not a necessary one. For the United Kingdom the stationarity hypothesis could only be accepted at a significance level of 10 per cent.

\section{3 - Co-integration between government revenues and expenditures}

In this section, fiscal sustainability in the EU-15 countries is studied by testing the existence of co-integration between government expenditures and revenues. Once more the variables are used in real terms, at 1990 prices, the data sources being given in the Appendix.

The first step is to test the existence of a unit root for all the expenditures and revenues series in level. ${ }^{18}$ The results for the augmented Dickey-Fuller tests (not presented in the interest of brevity) allow us to conclude that almost all series are not stationary in level. It was therefore necessary to test for the stationarity of the first differences. In general, it is possible to accept the stationarity of the first differences of the government expenditures and revenues series. One can then accept that the first differences of the original series, in real terms, are $\mathrm{I}(0)$, which means that the series in level are I(1). For some countries it is not possible however to accept the stationarity of the first differences of the original series. This is for instance the case of Germany, where expenditures are not I(1), and Luxembourg where revenues are not I(1), at the 5 per cent level. For Ireland and the United Kingdom neither expenditures nor revenues are $\mathrm{I}(1)$ at the 10 per cent level.

\footnotetext{
${ }^{18}$ Following the procedures popularised by Dickey and Fuller $(1979,1982)$.
} 
After assessing the stationarity of the government series, it is now possible to conduct co-integration tests between the revenues and the expenditures, for the countries where those variables are integrated of order $1 .{ }^{19}$ The test results for cointegration (not presented for space saving), allow us to reject the hypothesis of cointegration between government expenditures and government revenues for all countries. ${ }^{20}$ Therefore, with the series in level, it is not possible to accept the hypothesis of fiscal sustainability for those countries, for the period under analysis.

In a second stage the government expenditures and revenues were taken as a percentage of GDP, still in real terms. Visual inspection may give already a clue as can be seen by the examples of Figure 3, which depicts government expenditures and revenues, as a percentage of GDP, for Italy and Germany.

\section{[Insert Figure 3 about here]}

Unit root tests were then performed for the government expenditures and revenues as a percentage of GDP, the results being presented in Table 5. It is interesting to notice that now stationarity is the main conclusion, even if there are some exceptions. It is not possible to accept that both variables are I(1) in Denmark, where expenditures are not I(1); in France revenues are not I(1) and in Ireland where expenditures are not I(1), at least at 10 per cent level.

\section{[Insert Table 5 about here]}

The co-integration tests, for the countries were this procedure is now appropriate, were then performed with the government revenues and expenditures as a percentage of GDP. Obviously, Denmark, Ireland and France were excluded from these tests. The results are presented in Table 6.

[Insert Table 6 about here]

\footnotetext{
${ }^{19}$ Cointegration tests for non-stationary variables, as proposed by Engle and Granger (1987).

${ }^{20}$ All results are available from the author upon request.
} 
The test results allow the rejection of the co-integration hypothesis for all countries except for Austria, Germany and Netherlands. Those are precisely the countries for which, in the previous section, we have already accepted stationarity of the first difference of the stock of public debt. It seems therefore that the two sets of results are consistent.

However, the estimated coefficients for expenditures, in the co-integration equations, where government revenues is the dependent variable, are less than one. As a matter of fact, for each one-percentage point of GDP increase in public expenditures in Austria, Germany and Netherlands, public revenues only increase respectively by $0.86125,0.81977$ and 0.62202 percentage point of GDP. In other words, on average, for the period considered in this section, government expenditures in these three countries exhibited a higher growth rate than public revenues, challenging therefore also the hypothesis of fiscal policy sustainability.

\section{5 - Conclusion}

The fiscal policy sustainability issue was discussed in this paper, along with some previous considerations concerning the budget deficit arithmetic. The government budget constraint is the key element of this analysis and also the starting point to derive analytical formulations suitable for empirical testing.

Trough stationarity tests for the stock of public debt and co-integration tests between government revenues and expenditures, an attempt was made to assess the sustainability of fiscal policy in the EU-15 area, for the 1968-1997 period. The stationarity of the first difference of the stock of public debt, a sufficient condition for fiscal policy sustainability, was accepted only for three countries: Germany, Austria and Netherlands.

Empirical testing with co-integration tests was performed in a first stage with government revenues and expenditures in level (and in real terms). Almost for all series it was possible to conclude that the first differences were $\mathrm{I}(0)$ variables and the original series were therefore $I(1)$ variables. Nevertheless, it was not possible to conclude for the 
existence of co-integration between government expenditures and government revenues for none of those countries.

In a second stage, government expenditures and revenues were used as a percentage of GDP. With the exception of Denmark, France and Ireland, it was possible to conclude that all variables were I(1). Finally, and even if a co-integration vector was identified for Germany, Netherlands and Austria, the estimated coefficients for expenditures, in the co-integration equations for those countries, where public revenues is the dependent variable, are less than one. Therefore, these countries face also the problem of having a higher growth rate for expenditures than the growth rate of revenues. In other words, if fiscal policy were to be conducted in the future as it was in the past, there could still be some problems ahead, even for this set of countries that started, early in the 90s, making efforts in order to meet strict budgetary criteria.

The results reported above were obtained without considering the additional sources of government receipts: seigniorage revenues and privatisation revenues. As for the privatisation revenues, that information was not available for the EU-15 countries. Additional calculations could nevertheless be made, considering also the revenues from seigniorage. $^{21}$

\footnotetext{
${ }^{21}$ For instance Bravo and Silvestre (1999a), with data for Portugal, succeeded in finding a cointegration equation between real government revenues and expenditures, including also the revenues from privatisations and from seigniorage. The estimated coefficient from the cointegration equation however was also bellow unity.
} 


\section{Data appendix}

General government public debt: European Economy, $\mathrm{n}^{\circ}$ 65, European Commission, 1998.

Government expenditures and revenues at current prices: International Financial Statistics Yearbook, 1998, IMF; International Financial Statistics Yearbook, July 1999, IMF.

Consumer Price Index - $(1990=100)$ : Main Economic Indicators, Historical Statistics, 1960-1996, OECD, 1997, 1998; Main Economic Indicators, March, OECD, 1999.

GDP - at 1990 prices: International Financial Statistics Yearbook, 1998, IMF; International Financial Statistics Yearbook, July 1999, IMF.

\section{References}

Abel, A.; Mankiw, N., Summers, L., Zeckhauser, R. (1989). Assessing Dynamic Efficiency. Review of Economic Studies 56 (1): 1-20.

Afonso, A. (1999). Public Debt Neutrality and Private Consumption: some Evidence from the Euro Area. Research and Forecasting Department, Ministry of Finance of Portugal, Working Paper n ${ }^{\circ} 11$, June.

Ahmed, S., Rogers, J. (1995). Government budget deficits and trade deficits. Are present value constraints satisfied in long-term data? Journal of Monetary Economics 36 (2): 351-374.

Artis, M., Marcelino, M. (1998). Fiscal Solvency and Fiscal Forecasting in Europe. CEPR Discussion Paper 1836.

Athanasios, P., Sidiropoulos, M. (1999). The Sustainability of Fiscal Policies in the European Union. International Advances in Economic Research 5 (3), 289-307.

Baglioni, A., Cherubini, U. (1993). Intertemporal budget constraint and public debt sustainability: the case of Italy. Applied Economics 25 (2): 275-283.

Bartolini, L., Cottarelli, C. (1994). Government games and the sustainability of public deficits under uncertainty, Ricerche Economiche 48 (1): 1-22.

Bergman, M. (1998). Testing Government Solvency and the No Ponzi Game Condition. Forthcoming in Applied Economics Letters. 
Blanchard, O., Chouraqui, J., Hagemann, R., Sartor, N. (1990). The sustainability of fiscal policy: new answers to an old question. OECD Economic Studies 15, Autumn: 736.

Bohn, H. (1991). The Sustainability of Budget Deficits with Lump-Sum and with Income-Based Taxation. Journal of Money, Credit, and Banking 23 (3), Part 2: 581604.

Bohn, H. (1995). The Sustainability of Budget Deficits in a Stochastic Economy. Journal of Money, Credit, and Banking 27 (1): 257-271.

Bravo, A., Silvestre, A. (1999a). The sustainability of government deficits: an empirical test for Portugal. Mimeo.

Bravo, A., Silvestre, A. (1999b). Are the national public finances sustainable in the EU? A cointegration analysis. Working Paper 9/1999/DE, Instituto Superior de Economia e Gestão.

Buiter, W. (1985). A Guide to Public Sector Debt and Deficits, Economic Policy 1: 1379.

Buiter, W. (1999). The Fallacy of the Fiscal Theory of the Price Level. CEPR Discussion Paper n ${ }^{\circ}$ 2205, August.

Buiter, W., Patel, U. (1992). Debt, deficits, and inflation: An application to the public finances of India. Journal of Public Economics 47 (2): 171-205.

Caporale, G. (1995). Bubble finance and debt sustainability: a test of the government's intertemporal budget constraint. Applied Economics 27 (12): 1135-1143.

Chalk, N., Hemming, R. (2000). Assessing Fiscal Sustainability in Theory and Practice. IMF Working Paper, 00/81, April.

Crowder, W. (1997). The U.S. Federal Intertemporal Budget Constraint: Restoring Equilibrium Through Increased Revenues or Decreased Spending? http://wueconb.wustl.edu/vdkw_cgi/.

Cuddington, J. (1997). Analysing the Sustainability of Fiscal Deficits in Developing Countries. Policy Research Working Paper $n^{\circ}$ 1784, World Bank.

Dickey, D., Fuller, W. (1979). Distribution of Autoregressive Time Series with Unit Root. Journal of the American Statistical Association 74: 427-431.

Dickey, D., Fuller, W. (1981). The Likelihood Ratio Statistics for Autoregressive Time Series with a Unit Root. Econometrica 49: 1057-1072.

Elliot, G., Kearney, C. (1988). The intertemporal government budget constraint and tests for bubbles. Research Discussion Paper nº 8809, Reserve Bank of Australia. 
Engle, R., Granger, C. (1987). Co-Integration and Error Correction: Representation, Estimation, and Testing. Econometrica 55: 251-276.

Fève, P., Hénin, P. (1998). Assessing effective sustainability of fiscal policy within the G-7. Couverture Orange, CEPREMAP nº 9815, June.

Frisch, H. (1995). Government Debt and Sustainable Fiscal Policy. Economic Notes 24 (3): $561-580$.

Hakkio, G., Rush, M. (1991). Is the budget deficit "too large?" Economic Inquiry XXIX (3): 429-445.

Hamilton, J., Flavin, M. (1986). On the Limitations of Government Borrowing: A Framework for Empirical Testing. American Economic Review 76 (4): 808-816.

Haug, A. (1991). Co-integration and Government Borrowing Constraints: Evidence for the United States. Journal of Business \& Economic Statistics 9 (1): 97-101.

Haug, A. (1995). Has Federal budget deficit policy changed in recent years? Economic Inquiry XXXIII (3): 104-118.

Hénin, P. (1997). Soutenabilité des déficits et ajustements budgétaires. Révue Économique 48 (3): 371-395.

Joines, D. (1991). How large a federal deficit can we sustain? Contemporary Policy Issues IX (3): 1-11.

Keynes, J. (1923). A Tract on Monetary Reform, in The Collected Writings of John Maynard Keynes, vol. IV, Macmillan, 1971.

Kremers, J. (1988). The Long-Run Limits of U. S. Federal Debt. Economics Letters 28 (3): 259-262.

Kremers, J. (1989). U. S. federal indebtedness and the conduct of fiscal policy. Journal of Monetary Economics 23 (2): 219-238.

Liu, P., Tanner, E. (1995). Intertemporal solvency and breaks in the US deficit process: a maximum-likelihood co-integration approach. Applied Economics Letters 2 (7): 231235 .

Macklem, T., Rose, D., Tetlow, R. (1995). Government Debt and Deficits in Canada: A Macro Simulation Analysis. Working Paper 95-4, Bank of Canada.

Makrydakis, S., Tzavalis, E., Balfoussias, A. (1999). Policy regime changes and longrun sustainability of fiscal policy: an application to Greece. Economic Modelling 16 (1): 71-86.

McCallum, B. (1984). Are Bond-Financed Deficits Inflationary? A Ricardian Analysis. Journal of Political Economy 92: 123-135. 
O'Connell, S., Zeldes, S. (1988). Rational Ponzi Games. International Economic Review 29 (3): 431-450.

Payne, J. (1997). International evidence on the sustainability of budget deficits. Applied Economics Letters 12 (4): 775-779.

Quintos, C. (1995). Sustainability of the Deficit Process With Structural Shifts. Journal of Business \& Economic Statistics 13 (4): 409-417.

Sawada, Y. (1994). Are the heavily indebted countries solvent? Tests of intertemporal borrowing constraints. Journal of Development Economics 45 (2): 325-337.

Smith, G., Zin, S. (1991). Persistent Deficits and the Market Value of Government Debt. Journal of Applied Econometrics 6 (1): 31-44.

Spaventa, L. (1987). The Growth of Public Debt. IMF Staff Papers 34 (2): 374-399.

Tanner, E., Liu, P. (1994). Is the budget deficit "too large?": some further evidence. Economic Inquiry XXXII: 511-518.

Trehan, B., Walsh, C. (1988). Common trends, the government's budget constraint, and revenue smoothing. Journal of Economic Dynamics and Control 12 (2/3): 425-444.

Trehan, B., Walsh, C. (1991). Testing Intertemporal Budget Constraints: Theory and Applications to U.S. Federal Budget and Current Account Deficits. Journal of Money, Credit, and Banking 23 (2): 206-223.

Uctum, M., Wickens, M. (1997). Debt and deficit ceilings, and sustainability of fiscal policies: an intertemporal analysis. CEPR Discussion Paper $n^{\circ} 1612$, March.

Wilcox, D. (1989). The Sustainability of Government Deficits: Implications of the Present-Value Borrowing Constraint. Journal of Money, Credit, and Banking 21 (3): 291-306. 
Figure 1 - Simulated evolution of the debt-to-GDP ratio

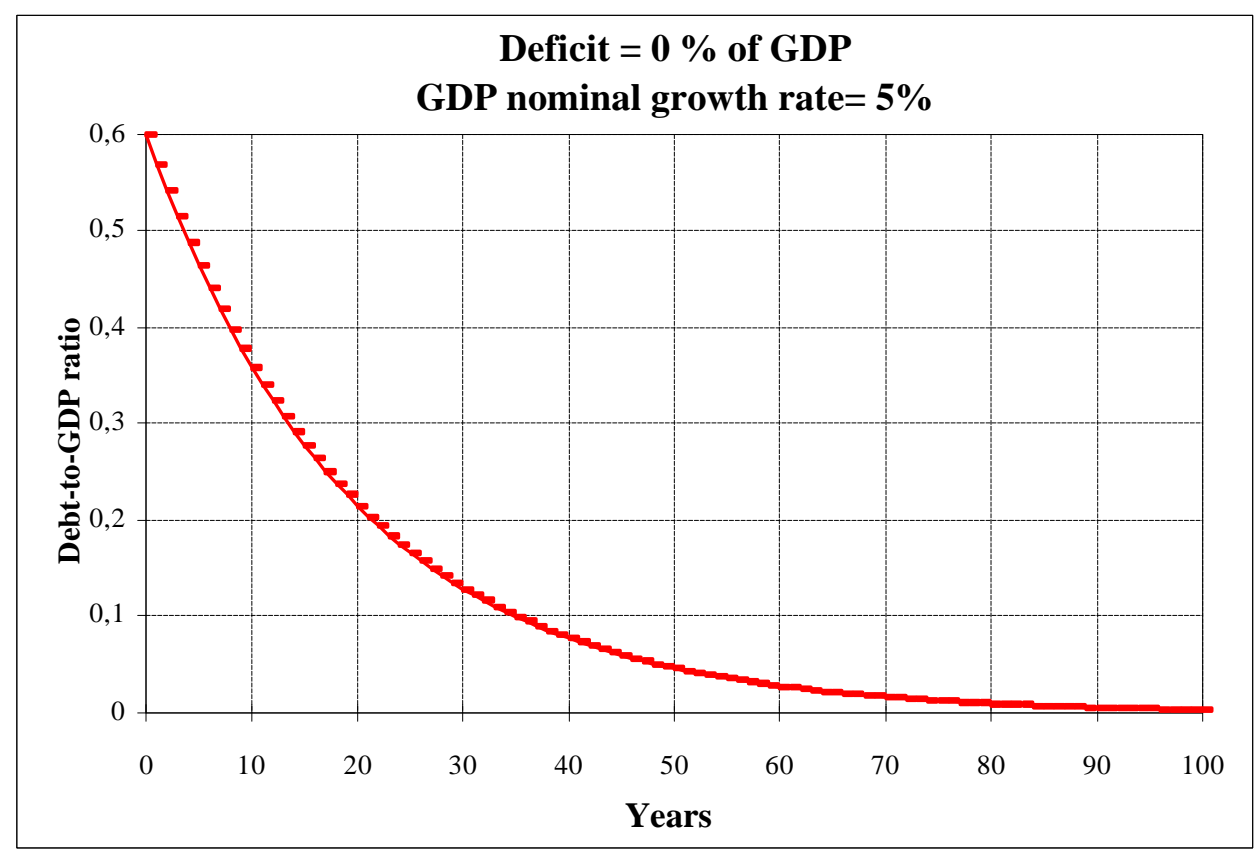


Table 1 - Arithmetic of budget deficits and public debt: an example

\begin{tabular}{|c|c|c|c|c|c|c|c|c|}
\hline \multirow{2}{*}{\multicolumn{2}{|c|}{$\begin{array}{l}\text { Debt/GDP (\%) } \\
\text { Deficit/GDP (\%) } \\
\end{array}$}} & 0 & 20 & 40 & 60 & 80 & 100 & 120 \\
\hline & & 0,0 & 0,9 & 1,8 & 2,7 & 3,6 & 4,5 & 5,4 \\
\hline \multicolumn{9}{|c|}{ Interests/GDP (\%) } \\
\hline \multirow{3}{*}{$\begin{array}{l}\text { Real } \\
\text { interest } \\
\text { rate }\end{array}$} & 3,5 & 0,0 & 1,1 & 2,2 & 3,3 & 4,4 & 5,5 & 6,6 \\
\hline & 5,0 & 0,0 & 1,4 & 2,8 & 4,2 & 5,6 & 7,0 & 8,4 \\
\hline & 6,5 & 0,0 & 1,7 & 3,4 & 5,1 & 6,8 & 8,5 & 10,2 \\
\hline \multicolumn{9}{|c|}{ Government revenues/GDP $(\%)^{2}$} \\
\hline \multirow{3}{*}{$\begin{array}{l}\text { Real } \\
\text { interest } \\
\text { rate }\end{array}$} & 3,5 & 40,0 & 40,2 & 40,4 & 40,6 & 40,8 & 41,0 & 41,2 \\
\hline & 5,0 & 40,0 & 40,5 & 41,0 & 41,5 & 42,0 & 42,5 & 43,0 \\
\hline & 6,5 & 40,0 & 40,8 & 41,6 & 42,4 & 43,2 & 44,0 & 44,8 \\
\hline \multicolumn{9}{|c|}{ Government expenditures (excluding interest payments)/GDP $(\%)^{3}$} \\
\hline \multirow{3}{*}{$\begin{array}{l}\text { Real } \\
\text { interest } \\
\text { rate }\end{array}$} & 3,5 & 40,0 & 39,8 & 39,6 & 39,4 & 39,2 & 39,0 & 38,8 \\
\hline & 5,0 & 40,0 & 39,5 & 39,0 & 38,5 & 38,0 & 37,5 & 37,0 \\
\hline & 6,5 & 40,0 & 39,2 & 38,4 & 37,6 & 36,8 & 36,0 & 35,2 \\
\hline
\end{tabular}

Notes:

1 - Deficit computed with a real GDP growth rate of 2,5 per cent and an inflation rate of 2 per cent;

2 - Calculations made with public expenditures at 40 per cent of GDP;

3 - Calculations made with government revenues at 40 per cent of GDP. 
Figure 2 - Public debt (as a \% of GDP)

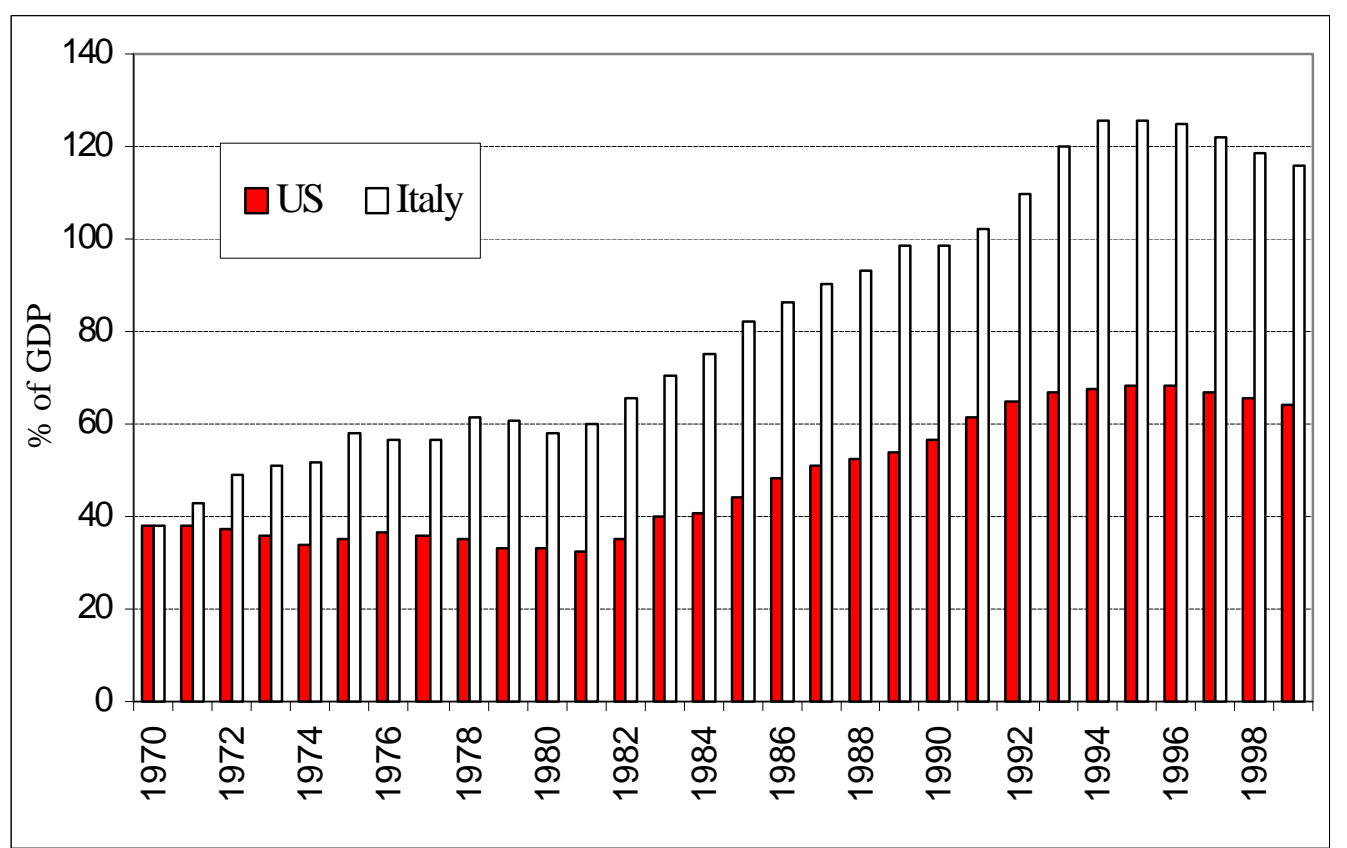


Table 2 - Some previous empirical evidence regarding fiscal policy sustainability

\begin{tabular}{|c|c|c|c|c|}
\hline Author and date & $\begin{array}{c}\text { Data } \\
\text { frequency }\end{array}$ & $\begin{array}{c}\text { Period and } \\
\text { country }\end{array}$ & Tests performed & Sustainability? \\
\hline $\begin{array}{l}\text { Hamilton and } \\
\text { Flavin (1986) }\end{array}$ & Annual & $\begin{array}{l}\text { 1962-1984 } \\
\text { (US) }\end{array}$ & $\begin{array}{l}\text { Deficit and public debt } \\
\text { stationarity }\end{array}$ & Yes \\
\hline $\begin{array}{l}\text { Trehan and Walsh } \\
\text { (1988) }\end{array}$ & Annual & $\begin{array}{l}1890-1983 \\
\text { (US) }\end{array}$ & Deficit stationarity & Yes \\
\hline $\begin{array}{l}\text { Kremers } \\
(1988)\end{array}$ & Annual & $\begin{array}{l}\text { 1920-1985 } \\
\text { (US) }\end{array}$ & Public debt stationarity & $\begin{array}{c}\text { Yes until 1981, no } \\
\text { afterwards }\end{array}$ \\
\hline $\begin{array}{l}\text { Elliot and Kearney } \\
\text { (1988) }\end{array}$ & Annual & $\begin{array}{l}\text { 1953/54-1986/87 } \\
\text { (Australia) }\end{array}$ & $\begin{array}{l}\text { Public revenues and } \\
\text { expenditures co-integration }\end{array}$ & Yes \\
\hline $\begin{array}{l}\text { Wilcox } \\
(1989)\end{array}$ & Annual & $\begin{array}{l}\text { 1960-1984 } \\
\text { (US) }\end{array}$ & Public debt stationarity & No \\
\hline $\begin{array}{l}\text { Hakkio and Rush } \\
\text { (1991) }\end{array}$ & Quarterly & $\begin{array}{l}\text { 1950:II-1988:IV } \\
\text { (US) }\end{array}$ & $\begin{array}{l}\text { Public revenues and } \\
\text { expenditures co-integration }\end{array}$ & No \\
\hline $\begin{array}{l}\text { Smith and Zin } \\
\text { (1991) }\end{array}$ & Monthly & $\begin{array}{l}\text { 1946:1-1984:12 } \\
\text { (Canada) }\end{array}$ & $\begin{array}{l}\text { Deficit and public debt } \\
\text { stationarity, co-integration }\end{array}$ & No \\
\hline $\begin{array}{l}\text { Trehan and Walsh } \\
\text { (1991) }\end{array}$ & Annual & $\begin{array}{l}\text { 1960-1984 } \\
\text { (US) }\end{array}$ & $\begin{array}{l}\text { Deficit and public debt } \\
\text { stationarity }\end{array}$ & Yes \\
\hline $\begin{array}{l}\text { Buiter and Patel } \\
\text { (1992) }\end{array}$ & Annual & $\begin{array}{l}\text { 1970/71-1987/88 } \\
\text { (India) }\end{array}$ & $\begin{array}{l}\text { Deficit and public debt } \\
\text { stationarity }\end{array}$ & No \\
\hline $\begin{array}{l}\text { Baglioni and } \\
\text { Cherubini (1993) }\end{array}$ & Monthly & $\begin{array}{l}\text { 1979:1-1991:5 } \\
\text { (Italy) }\end{array}$ & $\begin{array}{l}\text { Deficit and public debt } \\
\text { stationarity }\end{array}$ & No \\
\hline $\begin{array}{l}\text { Tanner and Liu } \\
\text { (1994) }\end{array}$ & Annual & $\begin{array}{l}\text { 1950-1989 } \\
\text { (US) }\end{array}$ & $\begin{array}{l}\text { Public revenues and } \\
\text { expenditures co-integration }\end{array}$ & $\begin{array}{c}\text { Yes, with a break in } \\
1982\end{array}$ \\
\hline $\begin{array}{l}\text { Liu and Tanner } \\
\text { (1995) }\end{array}$ & Quarterly & $\begin{array}{l}?-1991: I V \\
\text { (US) }\end{array}$ & $\begin{array}{l}\text { Public revenues and } \\
\text { expenditures co-integration }\end{array}$ & $\begin{array}{c}\text { Yes, with a break in } \\
1982\end{array}$ \\
\hline $\begin{array}{l}\text { Caporale } \\
\text { (1995) }\end{array}$ & $\begin{array}{c}\text { Semi- } \\
\text { annual and } \\
\text { annual }\end{array}$ & $\begin{array}{l}1960-1991 \\
\text { (EU countries) }\end{array}$ & $\begin{array}{l}\text { Deficit and public debt } \\
\text { stationarity }\end{array}$ & $\begin{array}{c}\text { No for Italy, } \\
\text { Greece, Denmark } \\
\text { and Germany }\end{array}$ \\
\hline $\begin{array}{l}\text { Quintos } \\
\text { (1995) }\end{array}$ & Quarterly & $\begin{array}{l}\text { 1947:II-1992:III } \\
\text { (US) }\end{array}$ & $\begin{array}{l}\text { Public revenues and } \\
\text { expenditures co-integration }\end{array}$ & $\begin{array}{l}\text { Yes until 1980, no } \\
\text { afterwards }\end{array}$ \\
\hline $\begin{array}{l}\text { Haug } \\
(1995)\end{array}$ & Quarterly & $\begin{array}{l}\text { 1950:I-1990:IV } \\
\text { (US) }\end{array}$ & $\begin{array}{l}\text { Public revenues and } \\
\text { expenditures co-integration }\end{array}$ & Yes \\
\hline $\begin{array}{l}\text { Ahmed and Rogers } \\
\text { (1995) }\end{array}$ & Annual & $\begin{array}{l}1692-1992 \text { (US) } \\
1792-1992 \text { (UK) }\end{array}$ & $\begin{array}{l}\text { Public revenues and } \\
\text { expenditures co-integration }\end{array}$ & Yes \\
\hline $\begin{array}{l}\text { Uctum and } \\
\text { Wickens } \\
\text { (1997) }\end{array}$ & Annual & $\begin{array}{l}1965-1994 \\
\text { (US and } 11 \mathrm{EU} \\
\text { countries) }\end{array}$ & Public debt stationarity & $\begin{array}{l}\text { Yes for Denmark, } \\
\text { Netherlands, } \\
\text { Ireland and France }\end{array}$ \\
\hline $\begin{array}{l}\text { Payne } \\
(1997)\end{array}$ & Annual & $\begin{array}{l}1949-1994 \\
\text { (G7 countries) }\end{array}$ & $\begin{array}{l}\text { Public revenues and } \\
\text { expenditures co-integration }\end{array}$ & Yes for Germany \\
\hline $\begin{array}{l}\text { Crowder } \\
(1997)\end{array}$ & Quarterly & $\begin{array}{l}\text { 1950:I-1994:II } \\
\text { (US) }\end{array}$ & $\begin{array}{l}\text { Public revenues and } \\
\text { expenditures co-integration }\end{array}$ & $\begin{array}{c}\text { Yes until 1982, no } \\
\text { afterwards }\end{array}$ \\
\hline $\begin{array}{l}\text { Artis and Marcelino } \\
\text { (1998) }\end{array}$ & Annual & $\begin{array}{l}196 \ldots-199 \ldots \\
\text { EU countries }\end{array}$ & Public debt stationarity & $\begin{array}{l}\text { Yes for, Austria, } \\
\text { Netherlands, UK }\end{array}$ \\
\hline $\begin{array}{l}\text { Fève and Hénin } \\
\text { (1998) }\end{array}$ & $\begin{array}{l}\begin{array}{c}\text { Semi- } \\
\text { annual }\end{array} \\
\end{array}$ & (G-7 countries) & Public debt stationarity & $\begin{array}{l}\text { Yes for US, UK } \\
\text { and Japan }\end{array}$ \\
\hline $\begin{array}{l}\text { Athanasios e } \\
\text { Sidiropoulos (1999) }\end{array}$ & Annual & $\begin{array}{l}\text { 1961-1994 (Spain, } \\
\text { Belgium, Greece, } \\
\text { Italy, Portugal) }\end{array}$ & $\begin{array}{l}\text { Public revenues and } \\
\text { expenditures co-integration }\end{array}$ & No \\
\hline Makrydakis (1999) & Annual & $\begin{array}{l}1958-1995 \\
\text { (Greece) }\end{array}$ & Public debt stationarity & No \\
\hline $\begin{array}{l}\text { Bravo and Silvestre } \\
\text { (1999b) }\end{array}$ & Annual & $\begin{array}{l}\text { 1970-1997 } \\
\text { (EU countries) }\end{array}$ & $\begin{array}{l}\text { Public revenues and } \\
\text { expenditures co-integration }\end{array}$ & $\begin{array}{l}\text { Yes for Germany, } \\
\text { Austria, Finland, } \\
\text { UK, Netherlands }\end{array}$ \\
\hline
\end{tabular}


Table 3 - Government revenues and expenditures in the UE-15 (as a \% of GDP)

\begin{tabular}{|c|c|c|c|c|c|c|}
\hline & & 1970 & 1980 & 1990 & 1997 & $\begin{array}{c}1997-1970 \\
\Delta \text { in pp }\end{array}$ \\
\hline \multirow[t]{2}{*}{ Austria } & Revenues & 28.3 & 34.0 & 34.7 & $37.8 \mathrm{~b}$ & 9.5 \\
\hline & Expenditures & 28.8 & 37.3 & 39.2 & $41.9 \mathrm{~b}$ & 13.1 \\
\hline \multirow[t]{2}{*}{ Belgium } & Revenues & 36.2 & 43.2 & 43.1 & 45.4 & 9.2 \\
\hline & Expenditures & 37.9 & 51.3 & 48.6 & 49.4 & 11.5 \\
\hline \multirow[t]{2}{*}{ Denmark } & Revenues & 35.1 & 36.3 & 38.6 & 40.0 & 4.9 \\
\hline & Expenditures & 32.6 & 38.9 & 39.3 & 41.9 & 9.3 \\
\hline \multirow[t]{2}{*}{ Finland } & Revenues & 21.0 & 26.8 & 31.8 & $34.1 \mathrm{~b}$ & 13.2 \\
\hline & Expenditures & 20.2 & 28.9 & 31.7 & $40.3 \mathrm{~b}$ & 20.1 \\
\hline \multirow[t]{2}{*}{ France } & Revenues & 21.1 & 40.2 & 41.1 & 42.5 & 21.4 \\
\hline & Expenditures & 20.7 & 40.3 & 43.2 & 46.0 & 25.3 \\
\hline \multirow[t]{2}{*}{ Germany } & Revenues & 24.6 & 29.0 & 28.9 & $31.6 \mathrm{~b}$ & 7.0 \\
\hline & Expenditures & 23.6 & 30.8 & 30.5 & $33.7 \mathrm{~b}$ & 10.1 \\
\hline \multirow{2}{*}{ Greece } & Revenues & 16.2 & 17.2 & 22.8 & $26.6 \mathrm{~b}$ & 10.4 \\
\hline & Expenditures & 18.2 & 19.9 & 36.6 & $36.4 \mathrm{~b}$ & 18.2 \\
\hline \multirow[t]{2}{*}{ Ireland } & Revenues & 27.8 & 26.9 & 31.6 & 30.9 & 3.1 \\
\hline & Expenditures & 33.8 & 51.4 & 33.3 & 30.3 & -3.5 \\
\hline \multirow[t]{2}{*}{ Italy } & Revenues & 12.9 & 21.4 & 31.0 & 32.7 & 19.8 \\
\hline & Expenditures & 16.9 & 30.3 & 41.6 & 34.3 & 17.4 \\
\hline \multirow[t]{2}{*}{ Luxembourg } & Revenues & $35.5 \mathrm{a}$ & 48.3 & 50.2 & $43.2 \mathrm{c}$ & 7.7 \\
\hline & Expenditures & $32.8 \mathrm{a}$ & 47.0 & 44.6 & $41.5 \mathrm{c}$ & 8.7 \\
\hline \multirow[t]{2}{*}{ Netherlands } & Revenues & 26.2 & 35.3 & 32.1 & 26.5 & 0.3 \\
\hline & Expenditures & 27.2 & 40.0 & 36.2 & 28.0 & 0.8 \\
\hline \multirow[t]{2}{*}{ Portugal } & Revenues & 15.9 & 24.9 & 35.0 & $39.9 \mathrm{~b}$ & 24.0 \\
\hline & Expenditures & 17.6 & 32.9 & 39.7 & $42.2 \mathrm{~b}$ & 24.6 \\
\hline \multirow[t]{2}{*}{ Spain } & Revenues & 12.5 & 14.2 & 20.3 & 21.6 & 9.8 \\
\hline & Expenditures & 13.3 & 17.8 & 23.1 & 24.1 & 10.8 \\
\hline \multirow[t]{2}{*}{ Sweden } & Revenues & 28.2 & 35.1 & 44.2 & 36.0 & 7.8 \\
\hline & Expenditures & 29.9 & 43.2 & 43.2 & 36.9 & 7.0 \\
\hline \multirow[t]{2}{*}{ UK } & Revenues & 37.1 & 36.6 & 37.0 & $36.8 \mathrm{c}$ & -0.3 \\
\hline & Expenditures & 35.3 & 41.3 & 36.2 & $42.1 \mathrm{c}$ & 6.8 \\
\hline
\end{tabular}

Notes: a - 1973; b - 1996; c -1995;

pp - percentage points.

Source: International Financial Statistics Yearbook, January 1999, IMF. 
Table 4 - Stationarity tests for the first difference of the stock of public debt

\begin{tabular}{|l|c|c|l|l|}
\hline \multicolumn{1}{|c|}{ Country } & Period & $\mathbf{k}$ & \multicolumn{1}{|c|}{ ADF(k) } & p-value \\
\hline Austria & $1970-1998$ & 3 & $-3.55907 *$ & 0.03348 \\
\hline Belgium & $1970-1998$ & 10 & -2.81240 & 0.19243 \\
\hline Denmark & $1971-1998$ & 10 & -2.82774 & 0.18694 \\
\hline Finland & $1970-1998$ & 10 & -2.31027 & 0.42828 \\
\hline France & $1977-1998$ & 7 & -1.83885 & 0.68573 \\
\hline Germany & $1970-1998$ & 10 & $-5.44895 *$ & 0.00003 \\
\hline Greece & $1970-1998$ & 2 & -1.40492 & 0.85946 \\
\hline Ireland & $1970-1998$ & 10 & 2.71084 & 1.00000 \\
\hline Italy & $1970-1998$ & 2 & -0.80827 & 0.96498 \\
\hline Luxembourg & $1975-1998$ & 8 & -0.67988 & 0.97444 \\
\hline Netherlands & $1973-1998$ & 0 & $-4.21636 *$ & 0.00423 \\
\hline Portugal & $1970-1998$ & 2 & -2.81547 & 0.19132 \\
\hline Spain & $1970-1998$ & 10 & -2.05625 & 0.57049 \\
\hline Sweden & $1970-1998$ & 3 & -2.77557 & 0.20606 \\
\hline United Kingdom & $1970-1998$ & 10 & $-3.14816 * *$ & 0.09523 \\
\hline
\end{tabular}

Notes: k - number of lags;

* - statistically significant at 5\%;

** - statistically significant at $10 \%$. 
Figure 3 - Government expenditures and revenues (as a \% of GDP)

3. a

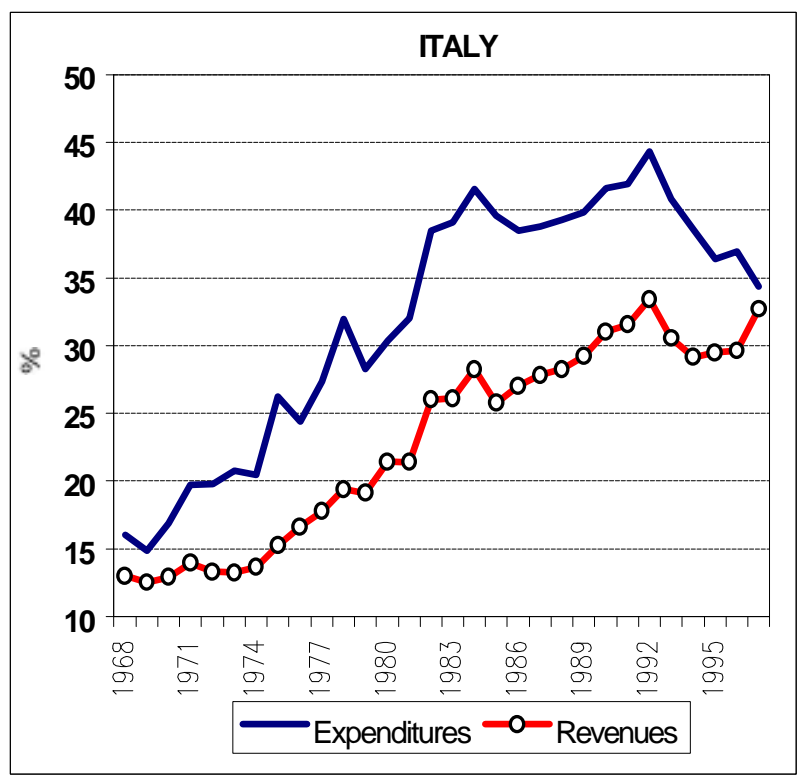

3. b

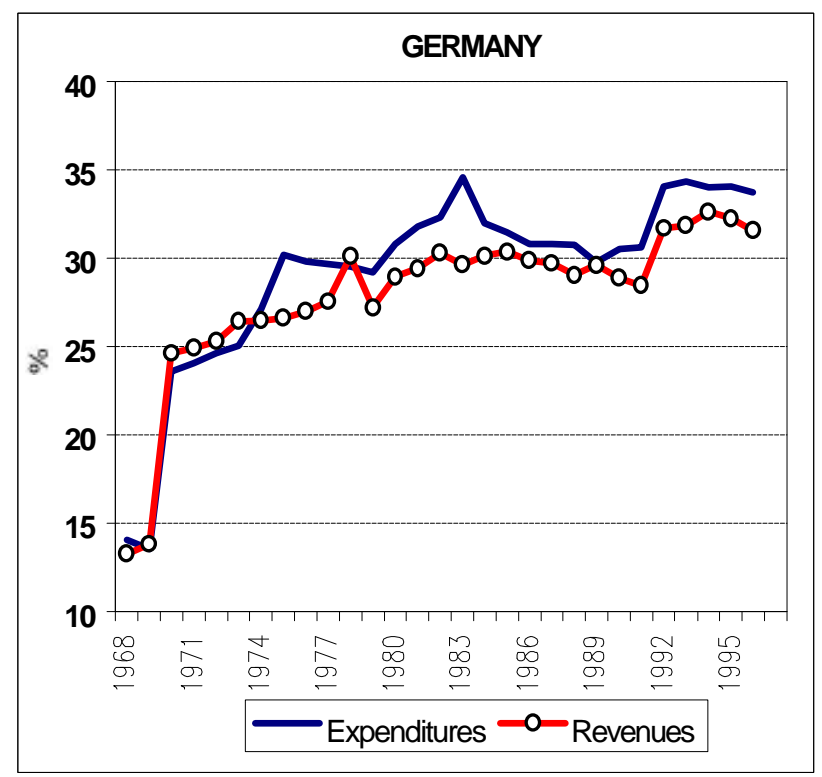


Table 5 - Stationarity of government revenues and expenditures, as a \% of GDP

\begin{tabular}{|c|c|c|c|c|c|c|c|c|c|}
\hline Country & Period & Variable & $\mathbf{K}$ & $\operatorname{ADF}(k)$ & p-value & Variable & $\mathbf{K}$ & $\mathbf{A D F}(\mathbf{k})$ & p-value \\
\hline \multirow[t]{2}{*}{ Austria } & \multirow[t]{2}{*}{ 1968-1996 } & $\mathrm{R}$ & 2 & -2.61131 & 0.27472 & $\Delta \mathrm{R}$ & 3 & -3.98619 & 0.00919 \\
\hline & & GG & 2 & -2.72236 & 0.22692 & $\Delta \mathrm{GG}$ & 2 & -3.66491 & 0.02478 \\
\hline \multirow[t]{2}{*}{ Belgium } & \multirow[t]{2}{*}{$1968-1995$} & $\bar{R}$ & 10 & -1.57420 & 0.80237 & $\Delta \mathrm{R}$ & 0 & -4.27244 & 0.00347 \\
\hline & & GG & 2 & -1.58932 & 0.79659 & $\Delta \mathrm{GG}$ & 0 & -3.89541 & 0.01231 \\
\hline \multirow[t]{2}{*}{ Denmark } & \multirow[t]{2}{*}{$1968-1995$} & $\mathrm{R}$ & 10 & -7.99454 & 0.00000 & $\Delta \mathrm{R}$ & 10 & -5.28879 & 0.00006 \\
\hline & & GG & 3 & -1.82799 & 0.69111 & $\Delta \mathrm{GG}$ & 10 & -2.72714 & 0.22499 \\
\hline \multirow[t]{2}{*}{ Finland } & \multirow[t]{2}{*}{ 1968-1996 } & $\mathrm{R}$ & 9 & -1.36484 & 0.87094 & $\Delta \mathrm{R}$ & 0 & -5.93834 & 0.00000 \\
\hline & & GG & 3 & -2.81051 & 0.19311 & $\Delta \mathrm{GG}$ & 3 & -3.30406 & 0.06559 \\
\hline \multirow[t]{2}{*}{ France } & \multirow[t]{2}{*}{ 1968-1997 } & $\mathrm{R}$ & 6 & -2.71440 & 0.23015 & $\Delta \mathrm{R}$ & 0 & -2.84262 & 0.18173 \\
\hline & & GG & 2 & -2.66777 & 0.24971 & $\Delta \mathrm{GG}$ & 0 & -4.15322 & 0.00526 \\
\hline \multirow[t]{2}{*}{ Germany } & \multirow[t]{2}{*}{ 1968-1996 } & $\mathrm{R}$ & 10 & -1.25937 & 0.89761 & $\Delta \mathrm{R}$ & 0 & -5.84873 & 0.00000 \\
\hline & & GG & 2 & -2.04376 & 0.57741 & $\Delta \mathrm{GG}$ & 0 & -4.02017 & 0.00823 \\
\hline \multirow[t]{2}{*}{ Greece } & \multirow[t]{2}{*}{$1968-1996$} & $\mathrm{R}$ & 2 & -2.87241 & 0.17162 & $\Delta \mathrm{R}$ & 0 & -4.76456 & 0.00054 \\
\hline & & GG & 10 & -2.04969 & 0.57413 & $\Delta \mathrm{GG}$ & 0 & -4.49539 & 0.00153 \\
\hline \multirow[t]{2}{*}{ Ireland } & \multirow[t]{2}{*}{ 1968-1997 } & $\mathrm{R}$ & 2 & -1.75374 & 0.72622 & $\Delta \mathrm{R}$ & 0 & -4.17565 & 0.00487 \\
\hline & & GG & 3 & -1.43315 & 0.85092 & $\Delta \mathrm{GG}$ & 8 & -2.50481 & 0.32556 \\
\hline \multirow[t]{2}{*}{ Italy } & \multirow[t]{2}{*}{ 1968-1997 } & $\mathrm{R}$ & 6 & -0.56396 & 0.98070 & $\Delta \mathrm{R}$ & 0 & -5.07427 & 0.00015 \\
\hline & & GG & 2 & -0.00041 & 0.99423 & $\Delta \mathrm{GG}$ & 0 & -4.93456 & 0.00027 \\
\hline \multirow[t]{2}{*}{ Luxembourg } & \multirow[t]{2}{*}{$1973-1995$} & $\mathrm{R}$ & 8 & -3.66467 & 0.02479 & $\Delta \mathrm{R}$ & 0 & -5.23815 & 0.00007 \\
\hline & & GG & 8 & -3.88821 & 0.01259 & $\Delta \mathrm{GG}$ & 0 & -3.75306 & 0.01909 \\
\hline \multirow[t]{2}{*}{ Netherlands } & \multirow[t]{2}{*}{ 1968-1997 } & $\mathrm{R}$ & 9 & -2.37051 & 0.39541 & $\Delta \mathrm{R}$ & 0 & -4.31641 & 0.00297 \\
\hline & & GG & 3 & 0.138120 & 0.99539 & $\Delta \mathrm{GG}$ & 0 & -8.37256 & 0.00000 \\
\hline \multirow[t]{2}{*}{ Portugal } & \multirow[t]{2}{*}{$1970-1996$} & $\mathrm{R}$ & 10 & -1.46786 & 0.83988 & $\Delta \mathrm{R}$ & 0 & -4.66846 & 0.00079 \\
\hline & & GG & 10 & -10.6291 & 0.00000 & $\Delta \mathrm{GG}$ & 0 & -4.73335 & 0.00061 \\
\hline \multirow[t]{2}{*}{ Spain } & \multirow[t]{2}{*}{ 1968-1997 } & $\mathrm{R}$ & 10 & -2.72492 & 0.22588 & $\Delta \mathrm{R}$ & 0 & -4.07642 & 0.00682 \\
\hline & & GG & 2 & -1.49054 & 0.83235 & $\Delta \mathrm{GG}$ & 0 & -5.63759 & 0.00001 \\
\hline \multirow[t]{2}{*}{ Sweden } & \multirow[t]{2}{*}{ 1968-1997 } & $\mathrm{R}$ & 3 & -1.81964 & 0.69521 & $\Delta \mathrm{R}$ & 1 & -3.80267 & 0.01642 \\
\hline & & GG & 2 & -0.74920 & 0.96971 & $\Delta \mathrm{GG}$ & 0 & -5.38683 & 0.00004 \\
\hline \multirow{2}{*}{$\begin{array}{l}\text { United } \\
\text { Kingdom }\end{array}$} & 1968-1995 & $\mathrm{R}$ & 2 & -3.45296 & 0.04470 & $\Delta \mathrm{R}$ & 0 & -5.09797 & 0.00013 \\
\hline & & GG & 6 & -2.13640 & 0.52566 & $\Delta \mathrm{GG}$ & 0 & -3.52510 & 0.03678 \\
\hline
\end{tabular}

Notes: R - government revenues, in real terms, as a percentage of GDP; GG - government expenditures in real terms, as a percentage of GDP; $\mathrm{k}$ - number of lags. 
Table 6 - Co-integration of government revenues and expenditures, as a percentage of GDP, in real terms, (for the countries where both variables are I (1))

\begin{tabular}{|c|c|c|c|c|c|}
\hline Country & $\begin{array}{c}\text { Dependent } \\
\text { variable }\end{array}$ & $\begin{array}{c}\text { Independent } \\
\text { variable }\end{array}$ & DF & p-value & $\begin{array}{c}\text { Co-integration } \\
\text { vector }\end{array}$ \\
\hline \multirow[t]{2}{*}{ Austria } & $\mathrm{R}$ & GG & -3.96219 & 0.03057 & {$\left[\begin{array}{ll}1 & -0.86215\end{array}\right]$} \\
\hline & GG & $\mathrm{R}$ & -2.57459 & 0.47903 & \\
\hline \multirow[t]{2}{*}{ Belgium } & $\mathrm{R}$ & GG & -3.34539 & 0.13880 & \\
\hline & GG & $\mathrm{R}$ & -1.18591 & 0.96375 & \\
\hline \multirow[t]{2}{*}{ Finland } & $\mathrm{R}$ & $\mathrm{GG}$ & -2.95500 & 0.28372 & \\
\hline & GG & $\mathrm{R}$ & -2.73381 & 0.39278 & \\
\hline \multirow[t]{2}{*}{ Germany } & $\mathrm{R}$ & GG & -3.80606 & 0.04687 & {$\left[\begin{array}{ll}1 & -0.81977\end{array}\right]$} \\
\hline & GG & $\mathrm{R}$ & -3.19631 & 0.18635 & \\
\hline \multirow[t]{2}{*}{ Greece } & $\mathrm{R}$ & $\overline{\mathrm{GG}}$ & -3.02820 & 0.25168 & \\
\hline & GG & $\mathrm{R}$ & -1.36778 & 0.94249 & \\
\hline \multirow[t]{2}{*}{ Italy } & $\mathrm{R}$ & GG & -2.89604 & 0.31113 & \\
\hline & GG & $\mathrm{R}$ & -1.73243 & 0.86570 & \\
\hline \multirow[t]{2}{*}{ Luxembourg } & $\mathrm{R}$ & GG & -1.04863 & 0.97465 & \\
\hline & GG & $\mathrm{R}$ & -2.30384 & 0.62694 & \\
\hline \multirow[t]{2}{*}{ Netherlands } & $\mathrm{R}$ & GG & -3.78200 & 0.04993 & {$\left[\begin{array}{ll}1 & -0.62202\end{array}\right]$} \\
\hline & GG & $\mathrm{R}$ & -2.61159 & 0.45866 & \\
\hline \multirow[t]{2}{*}{ Portugal } & $\overline{\mathrm{R}}$ & $\overline{\mathrm{GG}}$ & -1.19661 & 0.96273 & \\
\hline & GG & $\mathrm{R}$ & -1.55175 & 0.91040 & \\
\hline \multirow[t]{2}{*}{ Spain } & $\mathrm{R}$ & GG & -1.84925 & 0.82885 & \\
\hline & GG & $\mathrm{R}$ & -1.94064 & 0.79546 & \\
\hline \multirow[t]{2}{*}{ Sweden } & $\mathrm{R}$ & $\overline{\mathrm{GG}}$ & -2.82297 & 0.34687 & \\
\hline & GG & $\mathrm{R}$ & -1.62366 & 0.89432 & \\
\hline \multirow{2}{*}{$\begin{array}{l}\text { United } \\
\text { Kingdom }\end{array}$} & $\mathrm{R}$ & $\overline{\mathrm{GG}}$ & -3.35570 & 0.13586 & \\
\hline & GG & $\mathrm{R}$ & -2.17497 & 0.40275 & \\
\hline
\end{tabular}

Notes: R - government revenues, in real terms, as a percentage of GDP; GG - government expenditures in real terms, as a percentage of GDP; period under analysis, see Table 5. 